Contributions:

A Study design/planning

B Data collection/entry

C Data analysis/statistics

D Data interpretation

E Preparation of manuscript

F Literature analysis/search

$\mathrm{G}$ Funds collection

\title{
ASSESSMENT OF CLINICAL UTILITY OF PHONEMICALLY BALANCED WORD LISTS FOR ADULT SPEAKERS OF KANNADA
}

\section{Puttabasappa Manjula ${ }^{1 A B C D E F G}$, Jawahar Antony ${ }^{1 A B C D E F G}$, Keelara Shivaraju Sharath Kumar ${ }^{1 A B C D F G}$, Chinnaraj Geetha ${ }^{1 A B C D E F G}$}

Department of Audiology, All India Institute of Speech and Hearing, Mysore-570006, Karnataka, India

Corresponding author: Geetha C., Reader in Audiology, Department of Audiology, All India Institute of Speech and Hearing, Manasagangotri, Mysore-570006, Karnataka, India, Email ID: geethamysore.cs@gmail.com

\begin{abstract}
Objective: The present study aimed at standardizing the phonemically balanced word lists in the Kannada language for adults developed by Manjula et al. (2015).

Materials and Methods: Forty individuals with different degrees of sensorineural hearing loss were enrolled for the study. The word lists developed by Manjula et al. (2015) were presented monaurally under headphones at $40 \mathrm{~dB}$ SL (ref: PTA) in quiet. The number of correctly identified words was calculated for each list. The scores of all the lists in each group were statistically analyzed.

Results: The results revealed that there is list equivalency within each group on repeated measures ANOVA. The statistical analysis also revealed that the speech identification scores reduced significantly with an increase in the severity of hearing loss on MANOVA.

Conclusion: The lists developed by Manjula et al. (2015) are sensitive to different degrees of hearing loss. Hence, the lists can be a good speech identification tool for testing adults with hearing loss in routine speech identification testing, assessing hearing aid benefits, and for research purposes where multiple word lists are required.
\end{abstract}

Keywords: word lists $\bullet$ phonemic balance $\bullet$ Kannada language $\bullet$ hearing impairment $\bullet$ equivalency

\section{EVALUACIÓN DE LA UTILIDAD CLÍNICA DE LAS LISTAS DE PALABRAS FONÉTICAMENTE BALANCEADAS PARA USUARIOS ADULTOS DEL IDIOMA}

\section{KANNADA}

\section{Resumen}

Objetivo: El presente estudio tuvo como fin estandarizar las listas de palabras fonéticamente balanceadas en el idioma kannada para usuarios adultos.

Material y métodos: Para el estudio se calificaron 40 personas con distintos grados de hipoacusia neurosensorial. Las listas de palabras, elaboradas por Manjulai y colaboradores (2015), se presentaban monofónicamente en auriculares a $40 \mathrm{~dB}$ SL (ref: PTA) en silencio. Para cada lista se calculó el número de palabras correctamente identificadas. Los resultados de todas las listas se promediaron en cada grupo para un posterior análisis estadístico.

Resultados: Los resultados obtenidos utilizando el análisis de varianza ANOVA con medidas repetidas (MR) demostraron que las listas presentan resultados equivalentes en todos los grupos. El análisis estadístico MANOVA demostró además que los resultados del reconocimiento del habla empeoraban notablemente a medida que aumentaba la pérdida auditiva.

Conclusiones: Las listas empleadas para el idioma kannada son sensibles a distintos grados de pérdida auditiva. Por lo tanto, pueden ser una buena herramienta a la hora de evaluar el reconocimiento del habla en las visitas de control rutinario de adultos con hipoacusia, valorar los beneficios del uso de los audífonos y para fines de la investigación, donde se requieren listas de muchas palabras.

Palabras clave: listas de palabras $\bullet$ equilibrio fónico $\bullet$ idioma kannada $\bullet$ pérdida auditiva $\bullet$ equivalencia 


\title{
ОЦЕНКА КЛИНИЧЕСКОЙ ПРИГОДНОСТИ СПИСКА ФОНЕТИЧЕСКИ УРАВНОВЕШЕННЫХ СЛОВ ДЛЯ ВЗРОСЛЫХ, ВЛАДЕЮЩИХ ЯЗЫКОВ КАННАДА
}

\author{
Абстракт \\ Цель: Целью данного исследования была стандартизация списков фонетически уравновешенных слов на языке каннада для \\ взрослых. \\ Материал и методы: Для исследований были отобраны сорок человек с различной степенью тугоухости. Списки слов, подго- \\ товленные Manjula и др. (2015) воспроизводились в монофоническом звучании в наушниках с громкостью 40 дБ SL (ref: PTA) \\ в тишине. Количество правильно идентифицированных слов было подсчитано для каждого списка. Результаты всех списков \\ в каждой группе были усреднены для дальнейшего статистического анализа. \\ Результаты: Результаты, полученные с использованием дисперсионного анализа ANOVA с повторяющимися измерениями, \\ показали, что списки показывают взвешенные результаты в каждой группе. Статистический анализ MANOVA также показал, \\ что результаты распознавания речи значительно ухудшались по мере усиления степени нарушения слуха. \\ Выводы: Использованные списки для языка каннада позволяют выявить различную степень нарушения слуха. В связи с \\ этим они могут стать хорошим инструментом в типовых обследованиях взрослых с тугоухостью для исследования рас- \\ познавания речи, оценки пользы слуховых аппаратов, а также для исследований, в которых необходимы списки большо- \\ го количества слов.
}

Ключевые слова: списки слов • фонетическая уравновешенность • язык каннада • нарушения слуха • уравновешенность

\section{OCENA PRZYDATNOŚCI KLINICZNEJ FONEMICZNIE ZRÓWNOWAŻONYCH LIST SŁÓW DLA DOROSŁYCH UŻYTKOWNIKÓW JĘZYKA KANNADA}

\begin{abstract}
Streszczenie
Cel: Niniejsze badanie miało na celu standaryzację fonemicznie zrównoważonych list słów, , w języku kannada dla dorosłych.

Materiał i metody: Do badania zakwalifikowano czterdzieści osób z różnym stopniem niedosłuchu odbiorczego. Listy słów opracowane przez Manjula i in. (2015) były prezentowane monofonicznie w słuchawkach przy $40 \mathrm{~dB}$ SL (ref: PTA) w ciszy. Liczba poprawnie zidentyfikowanych słów została obliczona dla każdej listy. Wyniki wszystkich list w każdej grupie uśredniono dla dalszej analizy statystycznej.

Wyniki: Wyniki, uzyskane z wykorzystaniem analizy wariacji ANOVA z powtarzanymi pomiarami, wykazały, że listy dają równoważne wyniki w każdej grupie. Analiza statystyczna MANOVA wykazała również, że wyniki rozpoznawania mowy ulegały znacznemu pogorszeniu wraz ze wzrostem nasilenia ubytku słuchu.

Wnioski: Zastosowane listy dla języka kannada są wrażliwe na różne stopnie utraty słuchu. W związku z tym mogą być dobrym narzędziem podczas rutynowych kontroli osób dorosłych $\mathrm{z}$ niedosłuchem do badania rozpoznawania mowy, oceny korzyści $\mathrm{z}$ aparatów słuchowych oraz
\end{abstract} do celów badawczych, w których wymagane są listy wielu słów.

Słowa kluczowe: listy słów • równowaga foniczna • język kannada • uszkodzenie słuchu • równoważność

\section{Background}

Individuals with a hearing problem often complain of difficulty in understanding speech. In fact, the measurement of speech perception provides useful information for assessing communication difficulties experienced by listeners with hearing impairment. In addition, speech tests provide valuable information regarding how well the auditory system is performing in real world situations. Thus, speech tests form an important part of routine audiological evaluation $[1,2]$.

Speech perception tests administered to individuals with hearing loss can also be extended to rehabilitation, in particular, in assessing the ability of an individual to understand speech before and after amplification devices or cochlear implants are fitted [1]. Further, they help in making decisions about appropriate amplification and gauging the expected benefit from fitting a device [2]. The percentage loss or improvement in speech perception scores can often be more easily understood by patients than the degree of hearing loss [3].
The most common way of testing speech intelligibility at supra-threshold levels is to present the individual with a list of phonemically balanced test words [2]. The percentage of words correctly repeated is considered as the speech identification score (SIS) or speech recognition score (SRS).

Although there is a wide variety of speech material available, such as nonsense syllables [4] or sentences [5], word lists remain the most commonly used material as there is a fair amount of balance between face validity and redundancy when compared to nonsense syllables and sentences. The most commonly used words are monosyllabic or bisyllabic words in a word test. Many sets of monosyllabic material are available in English, among them the word lists of the Central Institute of the Deaf (CID W-22) and Northwestern University (NU-6) are commonly known. Bisyllables are preferred if the language does not have concrete monosyllabic words, and bisyllables provide more cues for intelligibility than monosyllables [4]. 
It is important to develop standardized speech test material in every language [6] which is suitable for testing across different degrees of hearing loss. Recently, new word tests have been developed in a number of foreign languages. A phonemically balanced word recognition test has been developed for the Ilocano language by Sagon [7]. Three word lists of 50 words each were developed by considering phonemic balance, syllable structure, and how common the words are. Muthuli et al. [8] developed a Thai word recognition test which consisted of five different word lists with 25 words each. In the Indian context, having language-specific material is a challenge as India is a multilingual country. Test material should be developed in different languages and needs to be validated across different degrees of hearing loss.

The phonemically balanced (PB) word list which was developed in Kannada (a Dravidian language family, spoken predominantly in the state of Karnataka, India) by Manjula et al. [9] has 24 word lists with 25 words in each list. These lists were standardized and validated for testing individuals with normal hearing. However, it is important not only that the speech material is validated in individuals with normal hearing, but also that the material should be sensitive enough to distinguish between different degrees of hearing loss. This requires the validation of these word lists for assessment of hearing and hearing device fitting. Validation will also help in research, as lists are needed to test various improvements in hearing aid technology and hearing aid parameters.

Killion [10] reported that individuals with hearing impairment have poorer word recognition scores even in quiet. In the presence of noise, individuals with mild hearing loss require a higher signal to noise ratio (SNR) than those with normal hearing, even when the testing is done at higher intensity levels. Hence, the study aimed to compare the scores obtained for 24 word lists between individuals with normal hearing and individuals with different levels of hearing loss and across different degrees of hearing loss in quiet.

\section{Materials and Method}

The aim of the present study was standardization of material developed by Manjula et al. [9] in the clinical population. The word lists developed by Manjula et al. consist of 24 equivalent word lists that can be used for adults in routine speech identification testing, assessing hearing aid benefits, and for research that requires multiple word lists. These words were selected from a pool of 1200 bisyllabic Kannada words (since Kannada has very few monosyllabic words). The words were collected from various sources such as text books, dictionary, magazines, and a corpus developed by the Central Institute of Indian Languages. The words were shortlisted based on familiarity and equality and constructed into 25 lists of 25 words each. They were standardized, in quiet and in noise, on individuals with normal hearing sensitivity [9].

The 24 standardized lists were then assessed for clinical utility in individuals with hearing impairment. The study used 40 participants with acquired sensorineural hearing loss having a flat type of configuration in one or both
Table 1. Mean age and age range for the four groups of participants with different degrees of hearing impairment

\begin{tabular}{lcc}
\hline Group & $\begin{array}{c}\text { Mean age } \\
\text { (years) }\end{array}$ & $\begin{array}{c}\text { Age range } \\
\text { (years) }\end{array}$ \\
\hline Mild hearing loss & 36.7 & 22 to 56 \\
\hline Moderate hearing loss & 52.5 & 23 to 60 \\
\hline Moderately severe hearing loss & 51.4 & 35 to 61 \\
\hline Severe hearing loss & 57.8 & 41 to 71 \\
\hline
\end{tabular}

ears. A flat configuration was defined as a difference in AC threshold of not more than $10 \mathrm{~dB}$ HL between adjacent octaves from 250 to $8000 \mathrm{~Hz}$. There were 10 individuals in each of the different degrees of hearing loss, i.e., mild, moderate, moderately severe, and severe. Their ages ranged from 22 to 71 years; the mean and age range are given in Table 1.

If the subject's loss was bilateral the ear for testing was selected randomly; otherwise the ear having the degree of hearing loss of interest for the current study was selected. If masking was required, the maximum effective masking was provided in the contralateral ear. The configuration of audiograms was restricted to flat type. The speech identification scores were in agreement with the degree of hearing loss, suggesting a cochlear hearing loss [11]. All the participants had A-type tympanograms and reflexes appropriate to their degree of hearing loss (either present, elevated, or absent). All the participants had normal speech and language abilities as reported and observed.

As mentioned, Killion [10] reported that individuals with hearing impairment have poorer recognition scores even in quiet, so individuals with mild hearing loss require higher SNR than those with normal hearing in the presence of noise, even when the testing is done at higher intensity levels. Because of this factor, in the present study individuals with hearing loss were tested only in quiet.

A dual channel audiometer (GSI 61), coupled with acoustically matched TDH 39 headphones housed in MX-41 AR ear cushions and with a B-71 bone vibrator, was utilized to estimate pure-tone hearing thresholds, speech recognition thresholds, and speech identification scores. A calibrated middle ear analyzer (GSI Tympstar) was used for obtaining a tympanogram and acoustic reflex threshold. The test stimulus was presented using a personal computer and delivered through Sennheiser HDA 200 headphones via the calibrated audiometer. The pure tone air-conduction thresholds for each participant were established in octave frequencies from 250 to $8000 \mathrm{~Hz}$ using the modified Hughson-Westlake method. The bone-conduction thresholds were also established using the same method for octave frequencies from 250 to $4000 \mathrm{~Hz}$.

The tympanometric measurements were done using a probe tone of $226 \mathrm{~Hz}$ at $85 \mathrm{~dB}$ SPL to evaluate the status of the middle ear. For acoustic reflex measurement, reflex-eliciting tones at 500,1000,2000, and $4000 \mathrm{~Hz}$ were presented both ipsilaterally and contralaterally to confirm the normal status of the middle ear. 


\section{Administration of developed word lists}

All 24 lists were administered to the individuals in quiet. The instrumentation, set-up, word lists, presentation lev$\mathrm{el}$, and procedure were the same as that used in Manjula et al. [9]. That is, the words were routed from a personal computer through an audiometer and delivered monaurally through Sennheiser HDA 200 headphones. The words were presented at $40 \mathrm{~dB}$ SL (ref: PTA). Participants were instructed to repeat the words, and the responses were recorded on a scoring sheet. Every correct response was given a score of 1 , and a score of 0 was given for incorrect responses or failure to repeat the word. The order of presentation of the word lists was randomized to avoid order effects. The scores obtained by the participants having different degrees of hearing loss in quiet were compared with scores obtained by individuals with normal hearing sensitivity at $40 \mathrm{~dB}$ SL (ref: PTA).

\section{Statistical analysis}

Descriptive statistics was done for the final lists administered to participants with hearing loss. Parametric statistical tests were used to compare the scores obtained between participants with normal hearing and those with hearing loss, and also between various degrees of hearing loss. The data on individuals with normal hearing as published in Manjula el al. [9] were compared with the data obtained from individuals with various degrees of hearing loss in the current study.

\section{Results}

The total number of correctly identified words in each list was tabulated for each group having a different degree of hearing loss. The mean and standard deviations are given in Table 2.

From Table 2, it can be seen that, within each group, the mean SIS is similar across different lists. Repeated measures ANOVA was administered to check the list equivalency within the mild, moderate, moderately severe, and severe hearing impairment groups. For all 24 word lists there was a significant main effect for the mild $[F(23,207)$ $=4.592, p>0.01]$; moderate $[F(23,207)=2.003, p>0.05]$; moderately severe $[F(23,207)=1,640, p>0.05]$; and severe

Table 2. Mean and standard deviation of speech identification scores (SISs) ( $\max =25$ ) for the four groups of participants having different degrees of hearing impairment together with a group of individuals with normal hearing sensitivity

\begin{tabular}{|c|c|c|c|c|c|c|c|c|c|c|}
\hline \multirow{2}{*}{ List no. } & \multicolumn{2}{|c|}{ Normal hearing* } & \multicolumn{2}{|c|}{ Mild } & \multicolumn{2}{|c|}{ Moderate } & \multicolumn{2}{|c|}{ Moderately-Severe } & \multicolumn{2}{|c|}{ Severe } \\
\hline & Mean & SD & Mean & SD & Mean & SD & Mean & SD & Mean & SD \\
\hline List1 & 24.73 & 0.69 & 22.30 & 0.95 & 17.70 & 0.67 & 14.30 & 2.06 & 11.40 & 0.84 \\
\hline List2 & 24.56 & 0.69 & 22.70 & 0.67 & 19.20 & 1.69 & 14.90 & 2.28 & 11.60 & 1.51 \\
\hline List3 & 24.33 & 0.87 & 22.80 & 0.92 & 18.20 & 1.69 & 15.20 & 2.35 & 9.60 & 0.97 \\
\hline List4 & 24.61 & 0.82 & 23.50 & 0.53 & 19.40 & 1.51 & 15.90 & 0.74 & 11.20 & 1.14 \\
\hline List5 & 24.15 & 0.95 & 24.10 & 0.74 & 18.60 & 1.43 & 15.40 & 0.52 & 9.90 & 1.20 \\
\hline List6 & 24.53 & 0.70 & 23.40 & 1.26 & 18.20 & 0.92 & 14.80 & 2.04 & 9.80 & 1.03 \\
\hline List7 & 24.56 & 0.81 & 22.30 & 1.16 & 18.80 & 1.40 & 15.00 & 2.26 & 9.90 & 0.57 \\
\hline List8 & 24.65 & 0.79 & 23.70 & 1.16 & 18.50 & 1.43 & 15.10 & 1.85 & 9.80 & 1.03 \\
\hline List9 & 24.46 & 0.87 & 23.70 & 0.82 & 18.70 & 1.25 & 15.50 & 1.51 & 10.80 & 1.03 \\
\hline List10 & 24.41 & 0.67 & 24.20 & 0.63 & 18.50 & 1.18 & 15.60 & 1.96 & 9.90 & 1.20 \\
\hline List11 & 24.65 & 0.57 & 24.00 & 0.94 & 18.90 & 0.99 & 14.80 & 1.55 & 11.80 & 1.55 \\
\hline List12 & 24.51 & 0.85 & 23.90 & 0.32 & 19.10 & 1.45 & 14.80 & 1.55 & 10.50 & 0.85 \\
\hline List13 & 24.56 & 0.78 & 23.80 & 1.23 & 18.90 & 0.99 & 15.20 & 0.42 & 10.40 & 1.35 \\
\hline List14 & 24.41 & 0.88 & 23.50 & 0.53 & 19.50 & 0.97 & 15.30 & 0.95 & 11.90 & 1.45 \\
\hline List15 & 24.55 & 0.85 & 23.90 & 0.88 & 18.70 & 1.06 & 15.10 & 1.29 & 10.20 & 0.42 \\
\hline List16 & 24.45 & 0.89 & 23.60 & 0.70 & 18.80 & 0.79 & 15.20 & 1.40 & 9.60 & 0.97 \\
\hline List17 & 24.33 & 0.95 & 23.40 & 0.52 & 18.90 & 1.20 & 15.20 & 0.79 & 9.20 & 1.14 \\
\hline List18 & 24.56 & 0.56 & 24.10 & 0.74 & 19.20 & 0.92 & 15.30 & 1.25 & 12.30 & 1.49 \\
\hline List19 & 24.15 & 3.00 & 24.10 & 0.88 & 18.90 & 0.99 & 14.70 & 1.25 & 9.50 & 1.08 \\
\hline List20 & 23.88 & 2.72 & 23.80 & 1.14 & 19.00 & 1.05 & 15.40 & 1.43 & 10.00 & 1.33 \\
\hline List21 & 24.56 & 0.76 & 23.50 & 1.18 & 19.30 & 1.57 & 14.70 & 1.57 & 10.50 & 0.85 \\
\hline List22 & 24.58 & 0.53 & 23.70 & 0.48 & 19.20 & 0.92 & 15.00 & 1.70 & 11.60 & 0.97 \\
\hline List23 & 24.50 & 1.08 & 23.60 & 1.07 & 19.10 & 0.88 & 15.70 & 1.49 & 11.30 & 0.95 \\
\hline List24 & 24.38 & 0.95 & 24.00 & 1.15 & 19.20 & 1.40 & 15.70 & 1.16 & 10.20 & 0.42 \\
\hline
\end{tabular}

* Data from Manjula et al. (2015) 
$[F(23,207)=7.362, p>0.01]$ hearing impairment groups . Hence, Bonferonni pair-wise comparisons were made. It was found that, in the mild group, only lists 2 and 9 were significantly different between each other (mean difference $=1.5, p<0.05$ ). In the moderate group, only lists 1 and 13 were significantly different between each other (mean difference $=1.5, p<0.05$ ). In the moderatelysevere group, none of the lists were significantly different from each other. In the severe group, lists 1, 2, and 8 were significantly different from the other lists.

Between-group analysis of SIS was carried out using MANOVA. The results revealed a statistically significant difference between the groups for all 24 lists $[F(53,224)$ $=9307.62, p<0.001]$. Hence, pair-wise comparisons were made using Bonferroni-adjusted correction, and Table 3 presents the results.

The results revealed that each group was significantly different from the others on all the lists. That is, the SIS decreased significantly with an increase in the severity of hearing loss for all lists.

\section{Discussion}

The present study involved assessing the clinical utility of the word lists developed and standardized by Manjula et al. [9]. The group with normal hearing obtained a mean SIS of $98.64 \%$ when the word list was presented in quiet at $40 \mathrm{~dB}$ SL (ref: SRT). Similar findings were obtained by Beattie et al. [12]; they obtained a speech discrimination score of approximately $95 \%$ at $32 \mathrm{~dB}$ SL for individuals with normal hearing sensitivity when CID W-22 and NU-6 test material was administered.

It can also be observed that the scores steadily decrease as the degree of loss increases, with the highest scores obtained by the mild group and the lowest scores by the severe group. Beattie et al. [12] found that participants with mild-to-moderate hearing impairment obtained a score of $85 \%$ in quiet upon administration of CID W-22 word lists. These results are similar to the results obtained in the present study. In the present study, a score of $85 \%$ results when the mild and moderate groups are combined.

Further, the effect of severe hearing impairment on speech identification scores is well known. The drastic decrease in speech identification ability in these individuals may be attributed to a loss of cochlear nonlinearity, decreased frequency selectivity, decreased temporal resolution, increased upward spread of masking, and the possible presence of dead regions [13-15]. Some of these factors could result in poor speech perception even in quiet [16]. Hence,

Table 3. Comparison of speech identification scores (SIS) between normal individuals and the four different clinical groups of participants using a Bonferonni pair-wise comparison across different lists

\begin{tabular}{|c|c|c|c|c|c|c|c|c|c|c|c|c|}
\hline \multirow{2}{*}{$\begin{array}{l}\text { Groups } \\
\text { compared }\end{array}$} & \multicolumn{12}{|c|}{ Mean difference (I-J) } \\
\hline & List 1 & List 2 & List 3 & List 4 & List 5 & List 6 & List 7 & List 8 & List 9 & List 10 & List 11 & List 12 \\
\hline N vs. M & $2.28^{\star}$ & $2.22^{*}$ & $1.85^{\star}$ & $1.30^{\star}$ & 0.46 & $1.42^{\star}$ & $1.72^{\star}$ & 0.42 & $1.03^{*}$ & 0.60 & 0.60 & $1.00^{\star}$ \\
\hline N vs. MD & $6.88^{*}$ & $5.72^{*}$ & $6.45^{\star}$ & $5.40^{\star}$ & $5.96^{\star}$ & $6.62^{\star}$ & $5.22^{*}$ & $5.62^{*}$ & $6.03^{*}$ & $6.30^{*}$ & $5.70^{\star}$ & $5.80^{\star}$ \\
\hline N vs. MS & $10.28^{*}$ & $10.02^{*}$ & $9.45^{*}$ & $8.90^{\star}$ & $9.16^{*}$ & $10.02^{*}$ & $9.02^{*}$ & $9.02^{*}$ & $9.23^{*}$ & $9.20^{*}$ & $9.80^{*}$ & $10.10^{*}$ \\
\hline N vs. S & $13.18^{*}$ & $13.32^{*}$ & $15.05^{*}$ & $13.60^{*}$ & $14.66^{*}$ & $15.02^{*}$ & $14.12^{*}$ & $14.32^{*}$ & $13.93^{*}$ & $14.90^{*}$ & $12.80^{*}$ & $14.40^{*}$ \\
\hline M vs. MD & $4.60^{*}$ & $3.50^{*}$ & $4.60^{*}$ & $4.10^{*}$ & $5.50^{*}$ & $5.20^{*}$ & $3.50^{*}$ & $5.20^{*}$ & $5.06^{*}$ & $5.70^{*}$ & $5.10^{*}$ & $4.80^{\star}$ \\
\hline M vs. MS & $8.00^{*}$ & $7.80^{*}$ & $7.60^{*}$ & $7.60^{*}$ & $8.70^{\star}$ & $8.60^{*}$ & $7.30^{*}$ & $8.60^{*}$ & $8.20^{*}$ & $8.60^{*}$ & $9.20^{*}$ & $9.10^{*}$ \\
\hline M vs. S & $10.90^{*}$ & $11.10^{*}$ & $13.20^{*}$ & $12.30^{*}$ & $14.20^{*}$ & $13.60^{*}$ & $12.40^{*}$ & $13.90^{\star}$ & $12.90^{*}$ & $14.30^{*}$ & $12.20^{\star}$ & $13.40^{*}$ \\
\hline M vs. MS & $3.40^{*}$ & $4.30^{\star}$ & $3.00^{\star}$ & $3.50^{\star}$ & $3.20^{\star}$ & $3.40^{\star}$ & $3.80^{\star}$ & $3.40^{\star}$ & $3.20^{\star}$ & $2.90^{\star}$ & $4.10^{\star}$ & $4.30^{\star}$ \\
\hline MD vs. S & $6.30^{*}$ & $7.60^{\star}$ & $8.60^{\star}$ & $8.20^{*}$ & $8.70^{\star}$ & $8.40^{\star}$ & $8.90^{\star}$ & $8.70^{\star}$ & $7.90^{\star}$ & $8.60^{\star}$ & $7.10^{*}$ & $8.60^{\star}$ \\
\hline \multirow[t]{2}{*}{ MS vs. S } & $2.90^{*}$ & $3.30^{*}$ & $5.60^{\star}$ & $4.70^{\star}$ & $5.50^{\star}$ & $5.00^{\star}$ & $5.10^{\star}$ & $5.30^{\star}$ & $4.70^{\star}$ & $5.70^{\star}$ & $3.00^{\star}$ & $4.30^{\star}$ \\
\hline & List 13 & List 14 & List 15 & List 16 & List 17 & List 18 & List 19 & List 20 & List 21 & List 22 & List 23 & List 24 \\
\hline$N$ vs. $M$ & $0.95^{*}$ & $0.93^{*}$ & $0.85^{*}$ & $1.18^{\star}$ & $1.40^{\star}$ & 0.60 & 0.75 & 0.93 & $1.20^{*}$ & $0.93^{*}$ & $1.15^{\star}$ & 0.56 \\
\hline N vs. MD & $5.85^{*}$ & $4.93^{*}$ & $6.05^{\star}$ & $5.98^{\star}$ & $5.90^{\star}$ & $5.50^{\star}$ & $5.95^{\star}$ & $5.73^{*}$ & $5.40^{\star}$ & $5.43^{*}$ & $5.65^{\star}$ & $5.36^{\star}$ \\
\hline N vs. MS & $9.55^{\star}$ & $9.13^{*}$ & $9.65^{*}$ & $9.58^{*}$ & $9.60^{*}$ & $9.40^{\star}$ & $10.15^{*}$ & $9.33^{*}$ & $10.00^{*}$ & $9.63^{*}$ & $9.05^{*}$ & $8.86^{*}$ \\
\hline N vs. S & $14.35^{*}$ & $12.53^{*}$ & $14.55^{*}$ & $15.18^{*}$ & $15.60^{*}$ & $12.40^{*}$ & $15.35^{*}$ & $14.73^{*}$ & $14.20^{\star}$ & $13.03^{*}$ & $13.45^{\star}$ & $14.36^{*}$ \\
\hline M vs. MD & $4.90^{*}$ & $4.00^{*}$ & $5.20^{*}$ & $4.80^{\star}$ & $4.50^{*}$ & $4.90^{\star}$ & $5.20^{*}$ & $4.80^{\star}$ & $4.20^{*}$ & $4.50^{*}$ & $4.50^{*}$ & $4.80^{*}$ \\
\hline$M$ vs. MS & $8.60^{*}$ & $8.20^{\star}$ & $8.80^{\star}$ & $8.40^{\star}$ & $8.20^{\star}$ & $8.80^{\star}$ & $9.40^{*}$ & $8.40^{\star}$ & $8.80^{\star}$ & $8.70^{*}$ & $7.90^{*}$ & $8.30^{\star}$ \\
\hline M vs. S & $13.40^{*}$ & $11.60^{*}$ & $13.70^{*}$ & $14.00^{*}$ & $14.20^{*}$ & $11.80^{*}$ & $14.60^{*}$ & $13.80^{*}$ & $13.00^{*}$ & $12.10^{*}$ & $12.30^{*}$ & $13.80^{*}$ \\
\hline M vs. MS & $3.70^{*}$ & $4.20^{*}$ & $3.60^{*}$ & $3.60^{*}$ & $3.70^{*}$ & $3.90^{\star}$ & $4.20^{\star}$ & $3.60^{\star}$ & $4.60^{\star}$ & $4.20^{\star}$ & $3.40^{*}$ & $3.50^{\star}$ \\
\hline MD vs. $S$ & $8.50^{*}$ & $7.60^{\star}$ & $8.50^{\star}$ & $9.20^{*}$ & $9.70^{\star}$ & $6.90^{\star}$ & $9.40^{*}$ & $9.00^{*}$ & $8.80^{\star}$ & $7.60^{*}$ & $7.80^{\star}$ & $9.00^{*}$ \\
\hline MS vs. S & $4.80^{*}$ & $3.40^{*}$ & $4.90^{*}$ & $5.60^{\star}$ & $6.00^{\star}$ & $3.00^{\star}$ & $5.20^{*}$ & $5.40^{\star}$ & $4.20^{\star}$ & $3.40^{*}$ & $4.40^{*}$ & $5.50^{\star}$ \\
\hline
\end{tabular}

${ }^{\star} p<0.001 ; N=$ normal; $M=$ mild; $M D=$ moderate; $M S=$ moderately-severe; $S=$ severe hearing loss 
it can be inferred that the developed material is sensitive to differences in speech identification abilities across different degrees of hearing loss.

In addition, one list was significantly different in the mild and moderate groups, and three lists in the severe group. These differences can be practically ignored, and equivalency of each list within each clinical group can be assumed since the mean in these lists does not differ by more than 1.5 scores and there was not much variation as revealed by the $S D$ values.

Hence, these standardized $24 \mathrm{~PB}$ word lists can be used in quiet in a clinical population as well. Because the material is sensitive to differences in speech identification abilities across different degrees of hearing loss, it can be assumed that the material could be applied not only in hearing assessment but also in the assessment of hearing aid benefits in individuals with different degrees of hearing loss.

\section{References}

1. Thibodeau LM. Speech audiometry. In: Audiology Diagnosis, eds Roeser RJ, Valente M, Hosford-Dunn H. New York: Thieme Medical Publishers; 2000, pp 281-310.

2. Gelfand SA. Essentials of Audiology. $3^{\text {rd }}$ ed. New York: Thieme Medical Publishers; 2000, pp 239-73.

3. Tyler RS. The use of speech perception tests in audiological rehabilitation: current and future research needs. J Rehab Res Dev, 1994; 27: 47-66.

4. Levitt H, Resnick SB. Speech reception by the hearing impaired: methods of testing and the development of new tests. Scan Audiol, 1978; 107(6): 130

5. Kollmeier B, Wesselkamp M. Development and evaluation of German sentence tests for objective and subjective speech intelligibility assessment. J Acoust Soc Am, 1997; 102: 2412-21.

6. Carhart R. Speech audiometry in clinical evaluation. Acta Otolaryngol 1952; 41: 18-42.

7. Sagon R. The development of a phonetically balanced word recognition test in the Ilocano language. Independent Studies and Capstones, Paper 382. Program in Audiology and Communication Sciences, Washington University School of Medicine; 2006. http://digitalcommons.wustl.edu/pacs_capstones/382.

8. Munthuli A, Sirimujalin P, Tantibundhit C, Onsuwan C, Kosawat K, Klangpornkun N. Constructing Thai phonetically balanced word recognition test in speech audiometry through large written corpora. Presented to 17th Oriental Chapter of the International Committee for the Co-ordination and Standardization of Speech Databases and Assessment Techniques (Oriental COCOSDA), Phuket, Thailand, 2014.

\section{Conclusion}

Phonemically balanced (PB) word lists form an important tool in routine speech identification testing while an audiometric test is being conducted. This study aimed to develop multiple PB word lists for adult speakers of Kannada. Hence, these 24 Kannada word lists can be used for adults during routine speech identification testing, for assessing hearing aid benefits, or for research purposes where multiple word lists in quiet are required.

\section{Acknowledgments}

This data is part of a project funded by the AIISH Research Fund. The authors thank the Director, All India Institute of Speech and Hearing, Mysore, and all participants.

\section{Conflict of interests: None}

9. Manjula P, Antony J, Kumar KSS, Geetha C. Development of phonemically balanced word lists in Kannada language for adults. J Hear Sci, 2015; 5(1): 22-30.

10. Killion MC. SNR loss: "I can hear what people say but I cannot understand them". Hear Review 1997; 4(12): 8-14.

11. Dubno J R, Lee F, Klein AJ, Matthews LJ, Lam CF. Confidence limits of maximum word recognition scores. J Speech Hear Res, 1995; 38: 490-502.

12. Beattie RC, Edgerton BJ, Svihovec D. A comparison of the Auditec of St Louis cassette recordings of NU-6 and CID W-22 on a normal-hearing population. J Speech Hear Dis, 1977; 42: 60-64.

13. Moore BCJ, Huss M, Vickers DA, Glasberg BR, Alcantara JI. A test for the diagnosis of dead regions in the cochlea. Br J Audiol, 2000; 34: 205-224.

14. Moore BCJ, Lynch C, Stone MA. Effects of the fitting parameters of a two-channel compression system on the intelligibility of speech in quiet and in noise. Br J Audiol, 1992; 26: 369-79.

15. Plomp R. Noise, amplification, and compression: considerations of three main issues in hearing aid design. Ear Hear, 1994; 15: 2-12.

16. Pekkerinan E, Salmivalli A, Suonpaa J. Effect of noise on word discrimination by subjects with impaired hearing, compared with those with normal hearing. Scand Audiol, 1990; 19: 31-6. 
